\title{
HUBUNGAN INTELLECTUAL CAPITAL, CORPORATE SOCIAL RESPONSIBILTY DAN CORPORATE GOVERNANCE TERHADAP KINERJA KEUANGAN
}

\author{
Supami Wahyu Setiyowati', Mardiana ${ }^{2}$ \\ ${ }^{1}$ Universitas Kanjuruhan, Indonesia \\ ${ }^{2}$ Universitas Islam Negeri Maulana Malik Ibrahim Malang, Indonesia
}

$\triangle$ Corresponding Author:

Nama Penulis: Supami Wahyu Setiyowati

E-mail: setiyo@unikama.ac.id

\section{Abstract}

Financial performance is an achievement obtained by companies, especially in the financial statements contained in financial reports for a certain period. The purpose of this study is to determine the relationship between intellectual corporate social responsibility (CSR) and corporate governance (CG) on financial performance in Islamic banking companies. This research is a quantitative research. Using purposive sampling. The population of Islamic banking companies is on the Indonesia Stock Exchange for the period 20142018. The sample is 6 Islamic banking companies. The data analysis technique uses multiple regression. The results showed that simultaneously and partially intellectual capital, corporate social responsibility, and corporate governance influenced financial performance. The conclusion is that the higher the intellectual capital, the higher the financial performance. The increased disclosure of corporate social responsibility shows an increase in financial performance. Implementation of corporate governance improves financial performance. Advice for investors and potential investors to see an increase in intellectual capital, disclosure of corporate social responsibility and corporate governance before investing to see the company's overall performance in order to benefit

Key words: Intelectual Capital, Corporate Sosial Responsibility, Corporate Governance, Financial performance

\section{Abstrak}

Kinerja keuangan merupakan prestasi yang di peroleh perusahaan khususnya dalam keuangan yang terdapat dalam laporan keuangan pada periode tertentu. Tujuan penelitian ini adalah untuk mengetahui hubungan intelectual capital, corporate sosial responsibility (CSR) dan Corporate governance (CG) terhadap kinerja keuangan pada perusahaan perbankan syariah. Penelitian ini merupakan penelitian kuantitatif. Menggunakan purposive sampling. Populasinya perusahaan perbankan syariah di Bursa Efek Indonesia periode 2014-2018. Menggunakan 6 perusahaan perbankan syariah sebagai sampel. Teknik analisis data menggunakan regresi berganda. Hasil penelitian menunjukkan bahwa secara simultan dan parsial intelectual capital, corporate 
social responsibility, dan corporate governance berpengaruh terhadap kinerja keuangan. Sehingga, semakin tinggi intelectual capital, akan semakin meningkat kinerja keuangan. Pengungkapan corporate sosial responbility yang meningkat menunjukan peningkatan kinerja keuangan. Implementasi corporate governance meningkatkan kinerja keuangan. Investor dan calon investor sebaiknya melihat peningkatan intelectual capital, pengungkapan corporate social reponsibility dan corporate governance sebelum berinvestasi untuk melihat kinerja perusahaan secara menyeluruh agar mendapatkan keuntungan.

Kata kunci: Intelectual Capital, Corporate Sosial Responsibility, Corporate Governance, kinerja keuangan

\section{PENDAHULUAN}

Perbankan dapat dikatakan memiliki kinerja keuangan yang baik yaitu apabila perusahaan menghasilkan produk andalan yang mempunyai inovasi dan dapat menarik perhatian investor. Modal dari investor akan digunakan perusahaan untuk membiayai operasi perusahaan. Perusahaan mempunyai modal yang cukup baik akan dapat berkembang sesuai tujuan yang telah ditetapkan. Sehingga perkembangan perusahaan dapat meningkatkan kinerja perusahaan.

Kinerja keuangan memiliki bentuk usaha formal yang digunakan untuk meningkatkan kinerja perusahaan seperti efisiensi dan efektifitas dalam memperoleh profit dan posisi kas. Hasil dari kinerja keuangan ini adalah diperlihatkan bagaimana kedepannya keuangan perusahaan. Perusahan yang telah mencapai tujuan yang di tetapkan adalah perusahaan yang berhasil (Kurniasari \& Ghozali, 2013).

Sesuai dengan Statistik Perbankan Syariah yang telah terbit melalui OJK, jumlah bank syariah meningkat setiap Tahun seperti yang dijelaskan dalam gambar 1 berikut ini:

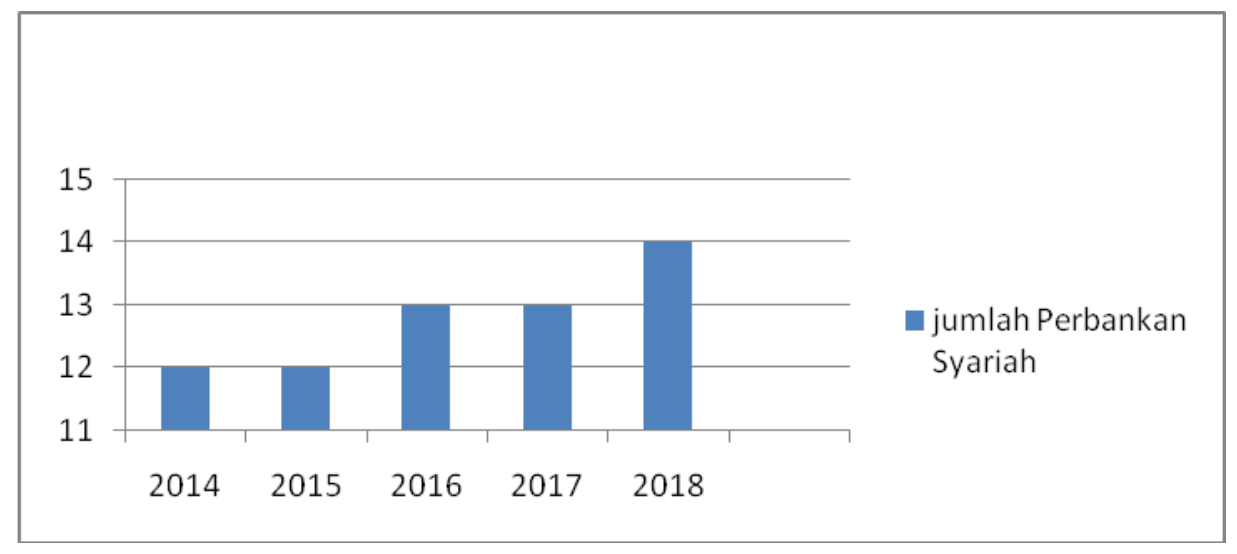

Gambar 1. Grafik Perbankan Syariah

Sumber: Statistik Perbankan Syariah tahun 2014-2018 
Pada tahun 2017 total asset perbankan syariah telah tercapai Rp. 424.181 miliyar, peningkatan yang terjadi yakni 18,98\% dibanding pada tahun sebelumnya. Total biaya dan piutang perbankan syariah Desember 2017 sebesar Rp 285.785 miliar, peningkatan 15,23\% dibandingkan tahun sebelumnya (OJK, n.d.). Perbankan syariah mampu mencetak Compounded Annual Growth Rate (CAGR) sebesar 15\%, lebih tinggi dari perbankan nasional yang mencatat CAGR 10\% (Rahajeng Kusumo Hastuti, n.d.). Hal ini menunjukkan bank syariah perkembangannya positif dari tahun 2014 ke tahun 2018. Pesatnya pertumbuhan perbankan syariah akan berpengaruh terhadap perekonomian Indonesia. Berkembangnya industri perbankan baik dari segi kuantitas bank, pengguna bank maupun komoditas bank, menuntut kapabilitas manusia pada kuantitas dan kualitas yang semakin meningkat. Kapabilitas manusia merupakan salah satu faktor intellectual capital perbankan. Intelellectual capital menciptakan elemen demi menaksir nilai basis kapabilitas manusia yang dimiliki perusahaan.

Intellectual capital (IC) adalah aset utama perusahaan yang sangat vital. Pengelolaan aset fisik dan intellectual capital harus tepat. Kemampuan manajemen dalam mengelola aset fisik dan intellectual capital sangat menentukan keberhasilan perusahaan untuk jangka pendek maupun jangka panjang (Kartika, 2013). IC yang di miliki perusahaan dapat berwujud pengetahuan, informasi kepemilikan yang akan digunakan untuk menciptakan produk atau kekayaan (Stewart, 2010).

Kinerja keuangan dipengaruhi oleh lingkungan perusahaan baik intern maupun ekstern perusahaan. Pengaruh lingkungan ini dapat dilihat pada corporate social responsibilty dan corporate governance. Implementasinya akan sangat mempengaruhi kinerja keuangan. Impementasi dari kedua variabel ini akan menciptakan keterkaitan yang sangat baik pada perusahaan dan lingkungannya. Image perusahaan akan baik di mata masyarakat.

Corporate Social Responsibilty (CSR) adalah implementasi tanggung jawab sosial dari perusahaan kepada masyarakat. Tanggung jawab sosial kepada masyarakat dapat berupa bantuan uang, peralatan maupun hadiah dari perusahaan kepada masyarakat baik individu maupun organisasi. CSR di berikan di wilayah perusahaan beroperasi (Brammer, Jackson, \& Matten, 2012).

Corporate Governance (CG) merupakan konsep perusahan untuk meningkatakan keberhasilan sesuai dengan tujuan yang ditetapkan sesuai peraturan dan nilai etika. Contohnya perusahaan akan meminimalisir biaya transaksi dan biaya agensi pada operasi perusahaan (Adi, 2011).

Penelitian (Artinah \& Muslih, 2016; Salim \& Karyawati, 2013; SW \& Firmansyah, 2012), menunjukan intellektual capital berpengaruh positif signifikan terhadap kinerja keuangan. Sedangkan menurut Lestari (2017) bahwa intelectual capital berpengaruh negatif signifikan terhadap kinerja 
keuangan. (Mahrani \& Soewarno, 2018) menyatakan bahwa corporate social responsibilty dan corporate governance berpengaruh terhadap kinerja keuangan.

Penelitian ini sangat penting dilakukan karena selama ini investor hanya melihat laba yang dihasilkan dari penggunaan aset tetap saja. Intellectual capital adalah aset tak berwujud yang akan memberikan keuntungan dimasa depan untuk keberlangsungan perusahaan. Imlementasi CSR dan CG juga merupakan faktor yang sangat penting bagi investor agar bisa melihat kinerja keuangan yang mendapatkan legitimasi dari masyarakat.

\section{KAJIAN PUSTAKA}

\section{Teori Stakeholder}

Teori Stakeholder menyatakan bahwa perusahaan beroperasi untuk kepentingannya sendiri dan masyarakat. Perusahaan harus memberikan manfaat bagi stakeholdernya (pemegang saham, kreditor, konsumen, supplier, pemerintah, masyarakat, analisis, dan pihak lainnya). Perusahaan beroperasi membutuhkan bantuan dari pihak luar dan masyarakat (Huang \& Kung, 2010).

\section{Teori Legitimasi}

Teori legitimasi merupakan keselarasan antara sistem nilai perusahaan dan sistem nilai masyarakat. Perusahaan memiliki kontrak dengan masyarakat untuk melakukan kegiatannya berdasarkan nilai-nilai yang berlaku dalam masyarakat dan bagaimana perusahaan menanggapi berbagai kelompok kepentingan untuk melegitimasi kepentingan perusahaan (Fatoni, Andini, \& Raharjo, 2016).

\section{Kinerja Keuangan}

Kinerja merupakan hal yang dilakukan perusahaan yang dapat melihat apakah perusahaan tersebut sudah menggunakan regulasi dalam keuangan secara baik dan benar yang menghasilkan gambaran keuangan perusahaan secara menyeluruh. Keuangan perusahaan yang baik dalam satu periode merupakan prestasi kerja dalam satu periode. Kinerja keuangan yang bagus akan digunakan perusahaan dalam keputusan yang berhubungan dengan lingkungan dalam maupun luar perusahaan (Irham, 2011).

Prestasi tersebut dapat dinilai menggunakan alat analis. Prestasi kerja khususnya dalam hal ini yakni keuangan dicapai oleh perusahaan dan tercantum pada laporan keuangan dari perusahaan. Kinerja keuangan dapat ternilai melalui alat analisis (Hery \& Si, 2015). Laporan keuangan perusahaan akan digunakan pihak dalam dan luar perusahaan dalam pengambilan keputusan.

Dari beberapa pengertian tersebut, kinerja keuangan merupakan suatu hal terkait pada keuangan perusahaan serta telah diaudit sesuai dengan alat- 
alat keuangan dan dari kinerja keuangan tersebut dapat dilihat baik buruknya serta tingkat pertumbuhan dan perkembangan keuangan perusahaan yang mencermikan prestasi perusahaan tersebut dalam periode tertentu.

\section{Intellectual Capital (IC)}

Intellectual Capital (IC) menurut (Soetedjo \& Mursida, 2014) ialah informasi, wawasan, hak kepemilikan intektual, pengalaman-pengalaman yang digunakan dalam penciptaan kekayaan. Ini berarti semua informasi yang digunakan untuk menghasilkan sesuatu yang dapat dinilai atau menambah nilai atau menciptakan kekayaan bagi perusahaan. IC ialah suatu asset tidak berwujud dengan kemampuannya memberikan nilai pada emiten serta khalayak umum dengan contoh paten, hak atas kekayaan intelektual, hak cipta dan waralaba (Aisyah \& Sudarno, 2014).

Intellectual capital adalah pengetahuan yang ada diperusahaan yang digunakan dalam operasi perusahaan yang menghasilkan keuntungan untuk perusahaan. Pengetahuan ini bisa menciptakan produk bagi perusahaan. Pengetahuan ini harus dipelihara dengan sebaik baiknya agar menghasilkan keuntungan perusahaan. IC ialah sumber daya yang terdapat pada perusahaan, dengan kata lain ialah aset tidak berwujud yakni sumber informasi yang didapatkan dan digunakan untuk pengambilan keputusan dan meningkatan nilai perusahaan.

\section{Corporate Social Responsibility (CSR)}

Corporate Social Responsibility (CSR) adalah komitmen perusahaan kepada masyarakat untuk memberikan kontribusi jangka panjang. Kontribusi perusahaan untuk menciptakan lingkungan yang lebih baik lagi di wilayah perusahaan beroperasi. Konsep ini secara tidak langsung membangun citra positif perusahaan (Hery, 2012). Menurut Resturiyani, (2012) CSR merupakan konsep integrasi yang menghubungkan bidang bisnis dan bidang sosial yang sejalur sesuai tujuan perusahaan. Konsep ini berarti bahwa perusahaan menganggap masyarakat sama dengan pemegang saham yang harus dilayani secara terus menerus.

Berdasarkan beberapa pengertian tersebut CSR ialah kewajiban perusahaan untuk memenuhi komitmen dalam aktivitas bisnis yang memiliki nilai etis untuk tujuan keseimbangan baik dari sisi internal dan eksternal maupun kepada masyarakat. Hal ini di lakukuan untuk mewujudkan pembangunan yang ramah terhadap lingkungan. 


\section{Corporate Governance (CG)}

Gorporate governance (CG) sebagai upaya mengarahkan dan mengendalikan kegiatan organisasi. Kegiatan tersebut meliputi kepentingan pemegang saham untuk memperoleh informasi yang benar dan tepat waktu. Gorporate governance merupakan hukum, peraturan, kaidah yang wajib dilakukan untuk meningkatkan kinerja perusahaan secara efektif dan efisien untuk jangka pendek maupun jangka Panjang (Pasorong, 2012).

Kerangka Konseptual

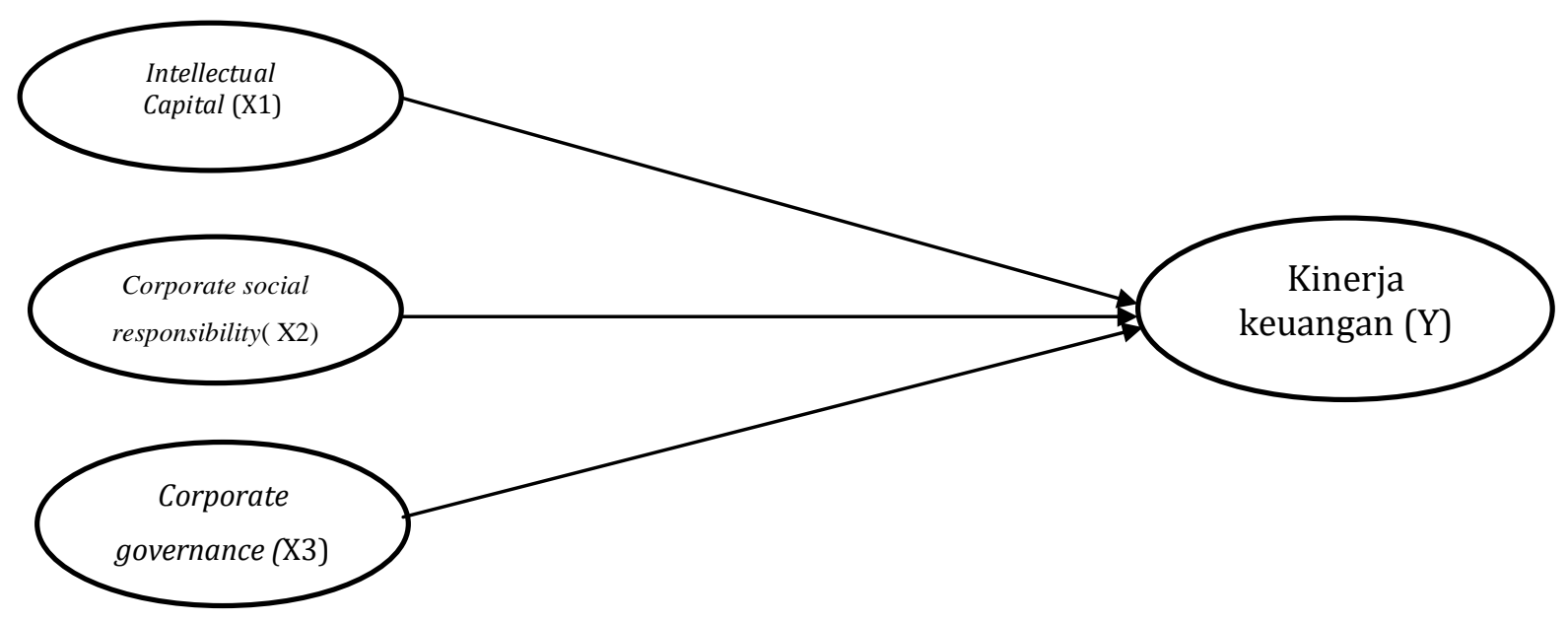

Gambar 2. Kerangka Konseptual

Sumber: Data diolah (2019)

\section{HIPOTESIS}

Intellectual Capital ialah sumber daya yang dimiliki perusahaan yang harus dipelihara dengan baik yang akan memberikan keuntungan di masa depan. Sumber daya dapat berupa modal intelektual yang digunakan perusahaan untuk menciptakan suatu produk unggulan. Penelitian (Artinah \& Muslih, 2016; Salim \& Karyawati, 2013; SW \& Firmansyah, 2012) menunjukkan IC mempengaruhi kinerja keuangan dengan positif dan signifikan. Hipotesis yang dirumuskan adalah:

H1: Intellectual Capital berpengaruh terhadap kinerja keuangan

CSR merupakan pertanggangjawaban perusahaan kepada masyarakat yang berada di wilayah operasi perusahaan. Tanggung jawab ini dapat berupa pemberdayaan lingkungan. (Mahrani \& Soewarno, 2018) menyatakan CSR mempengaruhi kinerja keuangan. Ini berarti peningkatan pengungkapan CSR secara nyata meningkatkan kinerja emiten perusahaan perbankan syariah periode 2014-2018.

H2: Corporate Social Responsibility berpengaruh terhadap kinerja keuangan 
Corporate governance merupakan sistem yang ada di perusahaan yang berfungsi sebagai pengelola usaha, controlling, dan pengendalian secara berkesinambungan. Hal ini dilakukan untuk meningkatkan nilai perusahaan dan memberikan perhatian kepada pemangku kepentingan. Penelitian (Mahrani \& Soewarno, 2018) menjelaskan bahwa corporate governance mempengaruhi kinerja keuangan. Ini berarti peningkatan kinerja corporate governance secara nyata meningkatkan kinerja keuangan perusahaan perbankan syariah periode 2014-2018. Hipotesis yang dirumuskan adalah:

H3: Corporate governance berpengaruh terhadap kinerja keuangan

\section{METODE}

Penelitian ini menggunakan metode kuantitatif. Variabel digunakan yaitu Intellectual Capital, Corporate Social Responsibility, Corporate Governance, dan kinerja keuangan. Populasi penelitian adalah perusahaan perbankan syariah yang terdaftar di Bursa Efek Indonesia pada tahun 20142018. Teknik pemilihan sampel berdasarkan kriteria yaitu sebagai berikut:

a. Perbankan yang masuk dalam BEI pada periode 2014-2018.

b. Perbankan yang masuk dalam BEI, yang menerbitkan laporan keuangan secara lengkap dari periode 2014-2018 dan telah diaudit serta terdapat data yang diperlukan untuk variabel penelitian ini.

Pada Tabel 1 dijelaskan klasifikasi sampel penelitian, setelah diseleksi berdasarkan kriteria yang ditentukan, maka diperoleh sampel sebanyak 6 bank syariah, yaitu Bank Muamalat Indonesia, Bank BRI Syariah, Bank BNI Syariah, Bank Syariah Mandiri, Bank Syariah Bukopin, dan Bank BCA Syariah. Sedangkan data yang di gunakan dalam penelitian ini adalah data sekunder dan teknik pengolahan data menggunakan regresi berganda dengan uji asumsi klasik dan uji regresi.

Tabel 1. Klasifikasi Sampel Penelitian

\begin{tabular}{clc}
\hline No & \multicolumn{1}{c}{ keterangan } & jumlah \\
\hline 1 & Perbankan yang masuk dalam BEI pada periode 2014-2018. & 14 \\
2 & Perbankan yang masuk dalam BEI, yang tidak menerbitkan & (8) \\
& $\begin{array}{l}\text { laporan keuangan secara lengkap dari periode 2014-2018 } \\
\text { dan telah diaudit serta terdapat data yang diperlukan untuk }\end{array}$ & \\
& variabel penelitian ini. & 6 \\
\hline
\end{tabular}

Sumber: Data diolah, 2019 
Supami Wahyu Setiyowati: Hubungan IC, CSR, dan CG Terhadap Kinerja Keuangan

HASIL DAN PEMBAHASAN

Hasil Uji Normalitas

Hasil uji normalitas dengan uji menggunakan Kolmogorov Smirnov.

Tabel 2. Hasil Uji Normalitas

\begin{tabular}{lll}
\hline Variabel & Hasil uji asymp sig & Keterangan \\
\hline Ic terhadap npm & 0.860 & Normal \\
Csr terhadap npm & 0.531 & Normal \\
Gcg terhadap npm & 0.455 & Normal \\
\hline
\end{tabular}

Sumber: Hasil Analisis (2019)

Hasil uji normalitas ditunjukkan bahwa asymp sig $>5 \%$, ini berarti data dinyatakan normal.

Hasil Uji Autokorelasi

Uji autokorelasi menggunakan runt test.

Tabel 3. Hasil Uji Autokorelasi

\begin{tabular}{lll}
\hline Variabel & Hasil tes run & Keterangan \\
\hline Ic terhadap npm & 0.076 & Tidak terjadi outokorelasi \\
\hline Csr terhadap npm & 0.056 & Tidak terjadi outokorelasi \\
\hline Gcg terhadap npm & 0.063 & Tidak terjadi outokorelasi \\
\hline
\end{tabular}

Sumber: Hasil Analisis (2019)

Hasil pengujian autokorelasi memberikan hasil run test $>$ dari 5\%, ini berarti data dinyatakan bebas dari outokorelasi

Tabel 4. Hasil Uji Multikolonieritas

\begin{tabular}{lcl}
\hline Variabel & Vif & Keterangan \\
\hline Ic terhadap npm & 1.000 & Tidak terjadi multikolonieritas \\
\hline Csr terhadap npm & 1.000 & Tidak terjadi multikolonieritas \\
\hline Gcg terhadap npm & 1.000 & Tidak terjadi multikolonieritas
\end{tabular}

Sumber: Hasil Analisis (2019)

Pada Tabel 4. diketahui bahwa semua VIF di bawah 10 dan dengan nilai tolerence diatas 0,5 , maka model regresi di nyatakan bebas dari Multikolinearitas. 
Supami Wahyu Setiyowati: Hubungan IC, CSR, dan CG Terhadap Kinerja Keuangan

\section{Hasil Uji Heteroskedastisitas}

Tabel 5. Hasil uji heteroskesdastisitas

\begin{tabular}{lll}
\hline Variable & Sig (2 tailed) & Keterangan \\
\hline IC terhadap npm & 0,358 & Tidak terjadi heteroskedastisitas \\
\hline Csr terhadap npm & 0.124 & Tidak terjadi heteroskedastisitas \\
\hline Gcg terhadap npm & 0,08 & Tidak terjadi heteroskedastisitas \\
\hline
\end{tabular}

Sumber: Hasil Analisis (2019)

Hasil Uji menunjukan bahwa nilai abs sig lebih besar 0,05 hal ini menunjukkan model terjadi heterokedstisitas.

\section{Hasil Analisis}

Hasil analisis IC, CSR dan GCG ke NPM diringkas sebagai berikut:

Tabel 6. Hasil Uji Regresi

\begin{tabular}{lccc}
\hline variable & Coeffisien & Sig & Keterangan \\
\hline IC ==> NPM & -0.463 & 0.008 & Berpengaruh \\
\hline CSR ==> NPM & 0.524 & 0.003 & Berpengaruh \\
\hline CG ==> NPM & 0.428 & 0.018 & Berpengaruh
\end{tabular}

Sumber: Hasil Analisis (2019)

Hasil uji regresi pada Tabel 6 menunjukkan bahwa variabel IC, CSR, dan CG berpengaruh terhadap Kinerja keuangan.

\section{Pembahasan}

\section{Intellectual Capital berpengaruh terhadap kinerja keuangan}

Hasil penelitian ini adalah Intelectual capital berpengaruh negatif terhadap kinerja keuangan. Hal ini terjadi karena perusahaan perbankan syariah Indonesia periode 2014-2018 belum memanfaatkan aset tak berwujud perusahaan secara efektif dan efisien. Ini membuktikan bahwa Intellectual capital berpengaruh negatif terhadap kinerja keuangan perusahaan. Penggunaan aset tak berwujud perusahaan harus ditingkatkan agar kinerja keuangan juga meningkat.

Hasil penelitian ini belum sepenuhnya menerapkan teori stake stakeholder. Pihak manajemen berharap perusahaan dapat melakukan aktivitas perusahaan sesuai kebutuhan stakeholder. Manejeman perusahaan yang baik dapat mengelola sumber daya yang ada di perusahaan untuk menciptakan value added yang dapat meningkatkan nilai perusahaan.

Hasil penelitian ini bertolak belakang dengan penelitian Kartika (2013) yang menyatakan bahwa IC adalah aset yang dimiliki perusahaan yang sangat vital. Pengelolaan aset fisik dan intellectual capital harus tepat. Kemampuan 
manajemen dalam mengelola aset fisik dan intellectual capital sangat menentukan keberhasilan perusahaan untuk jangka pendek maupun jangka panjang (Kartika, 2013).

Hasil penelitian ini mendukung dengan penelitian (Lestari, 2017) yang menyatakan intellectual capital berpengaruh negatif terhadap kinerja keuangan. Hal ini di sebabkan adanya indikasi penggunaan aset fisik yang masih dominan di perusahaan. Hasil penelitian ini bertolak belakang penelitian (Artinah \& Muslih, 2016; Salim \& Karyawati, 2013; SW \& Firmansyah, 2012) yang menyatakan bahwa intellectual capital mempengaruhi kinerja keuangan secara positif dan signifikan.

\section{Corporate Social Reponsibility berpengaruh terhadap kinerja keuangan.}

Hasil penelitian ini adalah CSR berpangaruh positif terhadap kinerja keuangan. Ini berarti perbankan syariah periode 2014-2018 sudah mengimplementasikan CRS secara baik yang berdampak pada peningkatan kinerja keuangan.

Hasil penelitian ini sesuai dengan teori legitimasi. Pengungkapan corporate social responsibility memberikan legitimasi masyarakat terhadap perusahaan. Perusahaan yang mendapatkan legitimasi dari masyarakat akan dapat meningkatkan reputasi dan citra baik di masyarakat. Reputasi dan citra baik dimasyarakat akan meningkatkan kinerja keuangan perusahaan

Hasil penelitian ini sesuai dengan penelitian (Mahrani \& Soewarno, 2018) yang menyatakan bahwa corporate social responbility berpengaruh terhadap kinerja keuangan. Ini berarti peningkatan pengungkapan corporate social responsibility secara nyata meningkatkan kinerja keuangan perusahaan perbankan syariah periode 2014-2018.

\section{Corporate Governance berpengaruh terhadap kinerja keuangan}

Kinerja corporate governance mampu memberikan dampak yang baik bagi peningkatan terhadap kinerja keuangan. Pada akhirnya tujuan perusahaan untuk menyejahterakan para stake holder akan tercapai. Semua informasi yang didapatkan dari dalam perusahaan serta implementasi keluar perusahaan menambah nilai perusahaan dimata investor dan calon investor. Manajemen diperusahaan perbankan syariah periode 2014-2018 telah mengimpementasikan corporate governance dengan baik. Dampaknya bisa dinikmati seluruh stake holder.

Penelitian yang dilakukan oleh Maharani \& Soewarno (2018) menjelaskan bahwa corporate governance mempengaruhi kinerja keuangan. Ini berarti peningkatan kinerja corporate governance secara nyata 
meningkatkan kinerja keuangan perusahaan perbankan syariah periode 2014-2018.

\section{KESIMPULAN}

Penjelasan terkait data yang telah dianalisis secara simultan dan parsial intellectual capital, corporate social responsibility, dan corporate governance mempengaruhi kinerja keuangan. Intellectual Capital merupakan sumber daya meliputi wawasan yang ada pada perusahaan yang pada akhirnya akan memberikan keuntungan di masa depan bagi perusahaan, dimana wawasan tersebut dapat menjadi modal intelektual apabila diciptakan, dipelihara dan ditransformasi dan diatur secara seksama.

CSR berpangaruh positif pada kinerja keuangan. Ini berarti perusahaan perbankan syariah periode 2014-2018 sudah mengimplementasikan CRS secara baik yang berdampak pada peningkatan kinerja keuangan. Implementasi CSR secara terus menerus akan menciptakan image perusahaan yang baik di masyarakat.

Corporate governance memberikan penjelasan keterkaitan antara pemegang saham yang dilakukan untuk penentuan arah serta kendali kinerja suatu perusahaan. Corporate governance berpengaruh terhadap nilai kinerja keuangan. Ini berarti implementasi corporate governance dan dilakukan secara optimal dari perusahaan, dapat memberi dampak pada peningkatan kinerja perusahaan.

\section{SARAN}

Saran kepada perusahaan untuk menggunakan intellectual capital dan asset fisik sesuai dengan proporsinya agar nilai perusahaan meningkat. Peningkatan implementasi corporate social responsilility dan corporate governance secara optimal akan dapat meningkatkan stabilitas kesehatan perusahaan. Untuk penelitian selanjutnya menambahkan variabel profitabilitas atau hutang sebagai variabel moderasi maupun intervening. Efek moderasi dan mediasi disarankan karena model tersebut lebih kompleks. Kekompleksan model menghasilkan penelitian yang lebih sesuai dengan kondisi sebenaranya.

\section{DAFTAR PUSTAKA}

Adi, J. U. W. (2011). Pengaruh Dewan Direksi, Dewan Komisaris, Dan Komite Audit Terhadap Penerimaan Opini Audit Going Concern (Studi Pada Perusahaan Manufaktur Yang Terdaftar Di Bei. Fakultas Ekonomi, UniversitasBrawijaya Malang.

Aisyah, C. N., \& Sudarno, S. (2014). Pengaruh Struktur Kepemilikan Dan R\&D Terhadap Luas Pengungkapan Modal Intelektual (Studi Empiris pada Perusahaan Keuangan yang Terdaftar di Bursa Efek Indonesia Tahun 
2012). Fakultas Ekonomika dan Bisnis.

Artinah, B., \& Muslih, A. (2016). Pengaruh intellectual capital terhadap capital gain (studi empiris terhadap perusahaan perbankan yang terdaftar di bursa efek Indonesia). Jurnal Ilmiah Bisnis Dan Keuangan, 1(1).

Brammer, S., Jackson, G., \& Matten, D. (2012). Corporate social responsibility and institutional theory: New perspectives on private governance. SocioEconomic Review, 10(1), 3-28.

Fatoni, F., Andini, R., \& Raharjo, K. (2016). Pengaruh Kepemilikan Publik, Return On Equity, Current Ratio, Umur Perusahaan Dan Company Size Terhadap Pengungkapan Corporate Social Responbility Pada Perusahaan Real Estate And Property Yang Terdaftar Di Bursa Efek Indonesia Periode 2011-2014. Journal Of Accounting, 2(2).

Hery, S. E. (2012). Akuntansi dan Rahasia Dibaliknya Untuk Para Manajer Non-Akuntansi. Jakarta: Bumi Aksara.

Hery, S. E., \& Si, M. (2015). Analisis Laporan Keuangan Pendekatan Rasio Keuangan. Bandung, Penerbit: CAPS.

Huang, C.-L., \& Kung, F.-H. (2010). Drivers of environmental disclosure and stakeholder expectation: Evidence from Taiwan. Journal of Business Ethics, 96(3), 435-451.

Irham, F. (2011). Analisa Laporan Keuangan, cetakan pertama. Penerbit: Alfabeta, Bandung.

Kurniasari, C., \& Ghozali, I. (2013). Analisis pengaruh rasio CAMEL dalam memprediksi financial distress perbankan Indonesia. Fakultas Ekonomika dan Bisnis.

Lestari, H. S. (2017). Pengaruh intellectual capital terhadap kinerja perusahaan asuransi di indonesia. Jurnal Manajemen, 21(3), 491-509.

Mahrani, M., \& Soewarno, N. (2018). The effect of good corporate governance mechanism and corporate social responsibility on financial performance with earnings management as mediating variable. Asian Journal of Accounting Research.

OJK. (n.d.). Statistik Perbankan Syariah. Retrieved July 18, 2020, from https://www.ojk.go.id/id/kanal/syariah/data-dan-statistik/statistikperbankan-syariah/default.aspx

Pasorong, A. M. (2012). Evaluasi Penerapan Prinsip-prinsip Good Corporate Governance Terhadap Prosedur Pemberian Kredit Pada Lembaga Perbankan (Studi Empiris Pada PT. Bank Central Asia (Persero) Tbk). Skripsi Jurusan Akuntansi Fakultas Ekonomi Universitas Hasanuddin.

Rahajeng Kusumo Hastuti. (2020). 5 Tahun Rerata Pertumbuhan Industri Perbankan Syariah 15\%. Retrieved July 18, 2020, from https://www.cnbcindonesia.com/syariah/20190608180708-29-

77170/5-tahun-rerata-pertumbuhan-industri-perbankan-syariah-15

Resturiyani, N. (2012). Pengaruh Pengungkapan Corporate Social Responsibility Terhadap Kinerja Keuangan. Bandung. Skripsi Universitas Pasundan.

Salim, S. M., \& Karyawati, G. (2013). Pengaruh modal intelektual terhadap kinerja keuangan. Journal of Business and Entrepreneurship, 1(2), 74-91.

Soetedjo, S., \& Mursida, S. (2014). Pengaruh Intellectual Capital Terhadap 
Kinerja Keuangan Pada Perusahaan Perbankan. Prosiding Simposium Nasional Akuntansi, Lombok.

Stewart, T. A. (2010). Intellectual Capital: The new wealth of organization. Currency.

SW, I. F., \& Firmansyah, R. (2012). Pengaruh intellectual capital terhadap kinerja keuangan perusahaan (Studi empiris perusahaan LQ 45). Jurnal Dinamika Akuntansi, 4(1). 